\title{
TRANSFER OF ORGANIC SUBSTANCES FROM RESIDUAL TANNERY BATHS TO THE MULTIFUNCTIONAL MINERAL COMPLEX MADE OF RED MUD
}

\author{
TRANSFERUL SUBSTANTELOR ORGANICE DIN FLOTE REZIDUALE DIN TĂBĂCĂRIE ÎN COMPLEXUL \\ MINERAL MULTIFUNCTIONAL REALIZAT DIN NĂMOL ROŞU
}

\author{
Mihaela-Doina NICULESCU*
}

INCDTP - Division: Leather and Footwear Research Institute, 93 Ion Minulescu St., sector 3, Bucharest, Romania, email: icpi@icpi.ro

\begin{abstract}
TRANSFER OF ORGANIC SUBSTANCES FROM RESIDUAL TANNERY BATHS TO THE MULTIFUNCTIONAL MINERAL COMPLEX MADE OF RED MUD ABSTRACT. This research highlights the possibility of individual treatment of baths resulting from processes prior to leather tanning for controlled capture of organic substances using mineral complex made by chemical modification of red mud, waste from the production of alumina from bauxite, using the Bayer process. Experiments have demonstrated the capacity of the mineral complex, obtained by chemical modification of red mud, to retain organic substances from wastewater. By treating the residual baths from operations prior to leather tanning with the red mud based mineral complex, chemical oxygen demand of residual baths can be reduced by about $85 \%$. The transfer of organic substances into the mineral complex is simple, effective and reproducible and does not cause particular problems in terms of toxicology and occupational safety.

KEY WORDS: organic substances, transfer, mineral complex
\end{abstract}

TRANSFERUL SUBSTANTELOR ORGANICE DIN FLOTE REZIDUALE DIN TĂBĂCĂRIE ÎN COMPLEXUL MINERAL MULTIFUNCTIONAL REALIZAT DIN NĂMOL ROŞU REZUMAT. Cercetările de faţă pun în evidenţă posibilitatea tratării individuale a flotelor rezultate din procesele preliminare ale tăbăcirii pieilor naturale, pentru captarea controlată a substanţelor organice, folosind complexul de minerale realizat prin modificarea chimică a nămolului roşu, deşeu de fabricaţie a aluminei din bauxită, prin procedeul Bayer. Experimentările au evidenţiat capacitatea complexului de minerale, realizat prin modificarea chimică a nămolului roşu, de a reţine substanţe organice din ape reziduale. Prin tratarea flotelor reziduale rezultate din operaţiile preliminare tăbăcirii pieilor cu complexul de minerale pe bază de nămol roşu, se poate reduce consumul chimic de oxigen al flotelor reziduale cu aproximativ $85 \%$. Procesul de transfer al substanţelor organice în complexul de minerale este simplu, eficace şi reproductibil şi nu induce probleme deosebite sub aspectul toxicologic şi al protecţiei muncii.

CUVINTE CHEIE: substanţe organice, transfer, complex mineral

LE TRANSFERT DE SUBSTANCES ORGANIQUES DES BAINS RÉSIDUELS DE LA TANNERIE DANS UN COMPLEXE MINÉRAL MULTIFONCTIONNEL À BASE DE LA BOUE ROUGE

RÉSUMÉ. Cette recherche mette en évidence la possibilité du traitement individuel des bains résultant des opérations préalables de tannage du cuir naturel pour l'absorption contrôlée de substances organiques à l'aide du complexe minéral fait par modification chimique de la boue rouge, un déchet de la production de l'alumine à partir de bauxite, en utilisant le procédé Bayer. Les expériences ont démontré la capacité du complexe minéral, obtenu par modification chimique de la boue rouge, de retenir les substances organiques retrouvées dans les eaux usées. En traitant le bain résiduel des opérations préliminaires de tannage des peaux en employant le complexe minéral à base de la boue rouge, on peut réduire la demande chimique en oxygène du bain résiduel par environ $85 \%$. Le transfert de substances organiques dans les complexes minéraux est simple, efficace et reproductible et ne provoque pas de problèmes particuliers en termes de toxicologie et de sécurité au travail.

MOTS CLÉS: substances organiques, transfert, complexe minéral

\section{INTRODUCTION}

Turning raw hides into semi-processed leather for manufacture of footwear, clothing, furniture upholstery, technical articles etc., involves circulation of large amounts of water and many chemical and mechanical processing operations, resulting in large quantities of solid waste and residual baths.

\section{INTRODUCERE}

Transformarea pieilor crude în semifabricate din piele destinate confecţionării de încălţăminte, haine, tapiţerii de mobilă, articole tehnice etc., implică vehicularea unor mari cantităţi de apă şi multe operaţii de prelucrare chimică şi mecanică, finalizate cu generarea unor mari cantităţi de deşeuri solide şi flote reziduale.

* Correspondence to: Mihaela-Doina NICULESCU, INCDTP - Division: Leather and Footwear Research Institute, 93 Ion Minulescu St., sector 3, Bucharest, Romania, email: icpi@icpi.ro 
An important issue in wastewater treatment is the organic load, which leads to the formation of large quantities of sludge in pre-treatment plants.

Among leather processing operations, the load richest in organic substances is that of wastewater from operations prior to tanning: washing, soaking, liming, which are designed to prepare the dermis for tanning.

The washing operation is designed to remove coarse residue, the excess of preservation agent and to facilitate rehydration of the hide. Residual baths contain a large amount of salt, as well as organic waste.

The soaking operation aims at rehydrating the hide and remove undesirable matter: preservatives, adherent impurities (dirt, blood, etc.), water soluble proteins (albumin) and the proteins soluble in salt solutions (globulins). Therefore, in addition to salt, sodium carbonate and emulsifiers, wastewater from this operation contains soluble proteins, blood serum and solid organic impurities.

The liming operation consists in removing the hair and epidermis. Residual baths contain hydrated lime, sodium sulphide, sodium hydrosulphide, and a large amount of proteins, especially keratin.

Out of these categories of organic substances found in wastewater from tanneries, dyes are a special class, coming either from the background dyeing operations, or from finishing operations, when metalcomplex dyes are used for emphasizing and tinting colour or for special aesthetic effects.

As a result of overall chemical treatment in pretreatment plants, the majority of the organic substance content in residual baths of natural leather processing is transferred to residual sludge, whose traceability is not always clear.

Depending on the particularities of each tannery, various procedures may be employed to reduce wastewater treatment costs, which are generally significant. One solution is to pre-treat water using pollutant-specific adsorbent materials, which involves the use of a range of materials, which often require considerable cost and labour leading to a very low economic efficiency.
O problemă importantă în tratarea apelor reziduale o ridică încărcătura organică, care conduce la formarea unor mari cantităţi de nămoluri în staţiile de pre-epurare.

Din procesele de prelucrare a pieilor, încărcătura cea mai bogată în substanţe organice o au apele reziduale provenite din operaţiile preliminare tăbăcirii: spălare, înmuiere, cenuşărire, care au rolul de a pregăti derma pentru operaţia de tăbăcire.

Operaţia de spălare are rolul de îndepărtare a reziduurilor grosiere, a surplusului de agent de conservare şi de a facilita rehidratarea pielii. Flotele reziduale conţin o mare cantitate de sare, dar şi reziduuri organice.

Operaţia de înmuiere are ca scop rehidratarea pielii şi îndepărtarea materialelor nedorite: agentul de conservare, impurităţi aderente (noroi, sânge etc.), proteinele solubile în apă (albumine) şi cele solubile în soluţii saline (globuline). Prin urmare, apele reziduale de la această operaţie, pe lângă sare, carbonat de sodiu şi emulgatori, conţin proteine solubile, ser sanguin şi impurităţi organice solide.

Operaţia de cenuşărire constă în eliminarea părului şi a epidermei. Flotele reziduale conţin var hidratat, sulfură de sodiu, hidrosulfură de sodiu, dar şi o mare cantitate de proteine, în special cheratine.

Faţă de aceste categorii de substanţe organice, din apele reziduale din tăbăcării, o clasă aparte o reprezintă coloranţii, care provin fie din operaţiile de vopsire de fond a pieilor, fie din operaţiile de finisare, când se folosesc coloranţi metal-complecşi pentru accentuarea şi nuanţarea culorii sau pentru efecte estetice deosebite.

În urma tratării chimice globale în staţiile de preepurare, cea mai mare parte din conţinutul de substanţe organice din flotele reziduale ale procesului de prelucrare a pieilor naturale este transferată în nămolurile reziduale, a căror trasabilitate nu este întotdeauna foarte clară.

În funcţie de particularităţile fiecărei tăbăcării, se pot adopta diverse proceduri de reducere a costurilor de tratare a apelor reziduale, care, în general, sunt semnificative. Una din soluţii o reprezintă pretratarea apelor cu materiale adsorbante specifice poluanţilor, ceea ce implică folosirea unei palete de materiale, care adesea generează costuri şi manoperă a căror cuantificare conduce la o eficienţă economică destul de scăzută. 
This paper has considered the possibility of individual treatment of residual baths for controlled capture of organic substances using a mineral complex developed through chemical modification of red mud [1], waste resulting from manufacturing alumina from bauxite, using the Bayer process.

Red mud is known as a material having a high capacity of capturing a wide range of pollutants, from heavy metals and anions to dyes [2-6].

Chemical modification of red mud in order to develop the capacity of capturing a specific compound (chromium, for instance) and physical conditioning [1, 7], does not negate the affinity of the material for other chemical species.

Previous research [8] showed that the mineral complex matrix has a multifunctional character, highlighting the following:

- The mineral complex made of red mud has a chromium retaining capacity of $60 \mathrm{mg} / \mathrm{g}$;

- In the acid $\mathrm{pH}$ range, the mineral complex is able to reduce the sulphate content by more than $85 \%$;

- In baths with weakly acid or alkaline $\mathrm{pH}$, the mineral complex may reduce silicon content by $30 \%$ to $80 \%$;

- Chemically modified red mud is able to retain phosphates from residual baths;

- Chemically modified red mud is able to retain amino acids with positively charged polar radical from protein polydispersions.

Recent results [9] have shown the considerable potential of mineral complex from red mud waste as management tool for the aquatic ecosystem, by highlighting its sorption capacity for dissolved organic carbon, phosphorus and for all species of nitrogen found in wastewater.

This paper discusses issues related to transferring organic substances from residual baths resulting from operations prior to leather tanning (washing, soaking, deliming), and the dyes used for leather finishing, found in tannery wastewater, into the mineral complex made from red mud in order to reduce the consumption of chemicals in the pre-treatment plant and the amount of sludge generated.
În lucrarea de faţă s-a luat în considerare posibilitatea tratării individuale a flotelor pentru captarea controlată a substanţelor organice, folosind complexul de minerale realizat prin modificarea chimică a nămolului roşu [1], un deşeu de fabricaţie a aluminei din bauxită, prin procedeul Bayer.

Nămolul roşu este recunoscut ca un material cu mare capacitate de captare a unui spectru larg de poluanţi, de la metale grele, anioni, până la coloranţi [2-6].

Modificarea chimică a nămolului roşu pentru dezvoltarea capacităţii de captare a unui compus specific (cum este cromul, de exemplu) şi condiţionarea fizică $[1,7]$ nu anulează afinitatea acestui material pentru alte specii chimice.

Cercetări anterioare [8] au demonstrat că matricea complexului mineral are un caracter multifuncţional, punându-se în evidenţă următoarele aspecte:

- Complexul mineral realizat din nămolul roşu are o capacitate de reţinere a cromului de $60 \mathrm{mg} / \mathrm{g}$;

- În domeniul de $\mathrm{pH}$ acid, complexul de minerale are capacitatea de a reduce cu peste $85 \%$ conţinutul de sulfaţi;

- În flote cu pH foarte uşor acid sau alcalin, complexul mineral poate reduce cu $30 \%$ până la $80 \%$ conţinutul de siliciu;

- Nămolul roşu modificat chimic este capabil de a reţine fosfaţi din flote reziduale;

- Nămol roşu modificat chimic este capabil de a reţine aminoacizi cu radical polar încărcat pozitiv din polidispersii proteice;

Rezultate recente [9] au demonstrat potenţialul considerabil pe care îl are complexul de minerale din deşeul de nămol roşu, ca instrument de gestionare a ecosistemului acvatic, prin evidenţierea capacităţii de sorbţie a acestuia pentru carbonul organic dizolvat, pentru fosfor şi pentru toate speciile de azot prezente în ape.

În lucrarea de faţă se discută aspecte legate de posibilitatea transferării substanţelor organice din flotele reziduale din operaţiile preliminare tăbăcirii pieilor (spălare, înmuiere, decalcificare), dar şi a coloranţilor folosiţi la finisarea pieilor, care ajung în apele reziduale din tăbăcării, în complexul de minerale realizat din nămolul roşu, în vederea reducerii consumului de substanţe chimice în staţia de preepurare şia cantităţii de nămol generat. 


\section{MATERIALS AND METHODS}

1. The multifunctional mineral complex made of red mud is a solid powdery material, of hematite red colour. The mineral complex composition, determined by X-ray fluorescence, is the following: $\mathrm{Na}_{2} \mathrm{O} 5.00 \%$; $\mathrm{MgO}$ 3.00\%; $\mathrm{Al}_{2} \mathrm{O}_{3}$ 20.00\%; $\mathrm{SiO}_{2}$ 9.00\%; $\mathrm{P}_{2} \mathrm{O}_{5} 1.50 \%$; $\mathrm{SO}_{3}$ 1.50\%; $\mathrm{Cl} 2.50 \%$; $\mathrm{CaO} 3.44 \%$; $\mathrm{TiO}_{2} 7.84 \%$; $\mathrm{V}_{2} \mathrm{O}_{5} 0.33 \%$; $\mathrm{Cr}_{2} \mathrm{O}_{3} 0.20 \%$; $\mathrm{MnO} 0.10 \% ; \mathrm{Fe}_{2} \mathrm{O}_{3} 47.10 \%$.

The BET specific surface area of the particles is of $48.0673 \mathrm{~m}^{2} / \mathrm{g}$.

The texture and morphology of particle surface, determined by scanning electron microscopy, are specific to mainly flat, large aggregates with large spaces in-between.

The point of zero charge (PZC), determined by potentiometric titration, is in the acid range, $\mathrm{pH}=6.21$ [10].

2. Residual baths from washing, soaking and deliming operations contain organic substances within the $14,000-21,000 \mathrm{mg} / \mathrm{dm}^{3}$ range.

3. Methods of analysis. Residual solutions were analyzed by gravimetric, volumetric and potentiometric methods, to determine the chemical oxygen demand as an expression of soluble and insoluble organic substances, and the $\mathrm{pH}$. Red mud sediments loaded with substances transferred from wastewater were dried in an oven, in a gradually increasing temperature system and were then cooled and ground. The ones resulting from adsorption of organic substances from baths of operations prior to tanning were analyzed by IR spectroscopy with a Jasco FT/IR-4200 spectrophotometer, while those derived from adsorption of metal-complex dyes were analyzed by UV-VIS spectroscopy using a JASCO V-550 UV-VIS spectrophotometer, Jasco.

\section{EXPERIMENTAL}

Experiments were conducted to determine the optimal parameters within which the mineral matrix of red mud can capture the excess organic matter from residual baths of leather processing operations, substances that are currently causing a difficult task for

\section{MATERIALE ŞI METODE}

1. Complexul de minerale multifuncţional realizat din nămol roşu este un material solid, pulverulent, de culoare roşu hematit. Compoziţia complexului mineral, determinată prin fluorescenţă de raze $X$, este următoarea: $\mathrm{Na}_{2} \mathrm{O} 5,00 \% ; \mathrm{MgO} 3,00 \% ; \mathrm{Al}_{2} \mathrm{O}_{3} 20,00 \%$; $\mathrm{SiO}_{2}$ 9,00\%; $\mathrm{P}_{2} \mathrm{O}_{5} 1,50 \%$; $\mathrm{SO}_{3} 1,50 \% ; \mathrm{Cl} 2,50 \% ; \mathrm{CaO}$ 3,44\%; $\mathrm{TiO} 2$ 7,84\%; $\mathrm{V}_{2} \mathrm{O}_{5}$ 0,33\%; $\mathrm{Cr}_{2} \mathrm{O}_{3} 0,20 \% ; \mathrm{MnO}$ $0,10 \% ; \mathrm{Fe}_{2} \mathrm{O}_{3} 47,10 \%$.

Suprafaţa specifică BET a particulelor este de $48,0673 \mathrm{~m}^{2} / \mathrm{g}$.

Textura şi morfologia suprafeţelor particulelor, determinate prin microscopie electronică de baleiaj, sunt specifice agregatelor mari, preponderent plate, $\mathrm{cu}$ spaţii largi între ele.

Punctul de sarcină zero (PSZ), determinat prin titrare potenţiometrică, se situează în domeniul acid, la $\mathrm{pH}=6,21[10]$.

2. Flotele reziduale din operaţiile de spălare, înmuiere şi decalcificare a pieilor, cu un conţinut de substanţe organice în intervalul $14.000-21.000 \mathrm{mg} / \mathrm{dm}^{3}$.

3. Metode de analiză. Soluţiile reziduale au fost analizate prin metode gravimetrice, volumetrice şi potenţiometrice, pentru stabilirea consumului chimic de oxigen, expresie a conţinutului de substanţe organice solubile şi insolubile, precum şi a pH-ului. Sedimentele de nămol roşu încărcate cu substanţele transferate din apele reziduale au fost uscate în etuvă, într-un regim crescător de temperatură, răcite şi mărunţite. Cele provenite de la adsorbţia substanţelor organice din flotele operaţiilor preliminare tăbăcirii au fost analizate prin spectrometrie IR, cu un spectrofotometru FT/IR4200, Jasco, iar cele provenite de la adsorbţia coloranţilor metal-complecşi, prin spectroscopie UV-VIS, cu un spectrofotometru UV-VIS, JASCO V-550, Jasco.

\section{PARTEA EXPERIMENTALĂ}

S-au realizat experimente pentru stabilirea parametrilor optimi în care matricea minerală a nămolului roşu poate capta excedentul de substanţe organice din flotele reziduale ale operaţiilor de prelucrare a pieilor, substanţe care în mod curent induc 
treatment plants and producing large amounts of sludge to be subsequently managed.

To establish process parameters, three technological models were developed and tested for three types of residual baths from washing, soaking and liming operations, known as having the highest load of organic matter.

\section{Experimental Techniques}

1. Chemically modified and conditioned red mud was dispersed in residual bath samples from the washing operation in a solid/liquid ratio of $1 / 10$. The adsorption was carried out at room temperature (about $20^{\circ} \mathrm{C}$ ) under stirring, at intervals of 1,2 and 3 hours.

2. Chemically modified and conditioned red mud was dispersed in residual bath samples from the soaking operation, in amounts equivalent to solid/liquid ratio of $1 / 10,1 / 15$ and $1 / 20$. The adsorption was carried out at room temperature (about $20^{\circ} \mathrm{C}$ ) under stirring, for 2 hours.

3. Chemically modified and conditioned red mud was dispersed in residual bath samples from the liming operation, as such and with adjusted $\mathrm{pH}$ using hydrochloric acid, from the initial $\mathrm{pH}$ of 12.03 to $\mathrm{pH} 9$ and $\mathrm{pH}$ 8. The adsorption was carried out at a solid/liquid ratio of $1 / 10$ at room temperature (about $20^{\circ} \mathrm{C}$ ) under continuous stirring for 2 hours.

4. Chemically modified and conditioned red mud was dispersed in residual bath samples containing metal-complex dyes in a solid/liquid ratio of $1 / 10$. Adsorption process was carried out at room temperature (about $20^{\circ} \mathrm{C}$ ) under intermittent stirring 5 minutes stirring, 55 minutes rest - for 6 hours.

After completion of stirring programme, dispersions were filtered under vacuum.

\section{RESULTS AND DISCUSSIONS}

Residual baths from operations prior to tanning (washing, soaking, liming) were analyzed before and after treatment with mineral complex of chemically modified red mud. o sarcină dificilă staţiilor de epurare şi generează mari cantităţi de nămoluri ce trebuie gestionate ulterior.

Pentru stabilirea parametrilor tehnologici, s-au elaborat şi experimentat trei modele tehnologice pentru trei tipuri de flote reziduale, provenite de la operaţiile de spălare, înmuiere şi cenuşărire a pieilor, recunoscute ca având cele mai mari încărcări de materii organice.

\section{Tehnici experimentale}

1. Nămolul roşu modificat chimic şi condiţionat a fost dispersat în probe de flote reziduale provenite de la operaţia de spălare a pieilor într-un raport solid/lichid de $1 / 10$. Procesul de adsorbţie $s$-a desfăşurat la temperatură ambiantă (aproximativ $20^{\circ} \mathrm{C}$ ), sub agitare, în intervale de timp de 1, 2 şi 3 ore.

2. Nămolul roşu modificat chimic şi condiţionat a fost dispersat în probe de flote reziduale provenite de la operaţia de înmuiere, în cantităţi echivalente unor rapoarte solid/lichid de $1 / 10,1 / 15$ şi $1 / 20$. Procesul de adsorbţie s-a desfăşurat la temperatură ambiantă (aproximativ $20^{\circ} \mathrm{C}$ ), sub agitare, timp de 2 ore.

3. Nămolul roşu modificat chimic şi condiţionat a fost dispersat în probe de flote reziduale provenite de la operaţia de cenuşărire, brute şi cu pH-ul modificat cu acid clorhidric, de la pH-ul iniţial de 12,03, la pH 9 şi pH 8. Procesul de adsorbţie s-a desfăşurat la un raport solid/lichid de $1 / 10$, la temperatură ambiantă (aproximativ $20^{\circ} \mathrm{C}$ ), sub agitare continuă, timp de 2 ore.

4. Nămolul roşu modificat chimic şi condiţionat a fost dispersat în probe de ape reziduale $\mathrm{cu}$ conţinut de coloranţi metal-complecşi, într-un raport solid/lichid de $1 / 10$. Procesul de adsorbţie s-a desfăşurat la temperatură ambiantă (aproximativ $20^{\circ} \mathrm{C}$ ), cu agitare intermitentă, 5 minute agitare, 55 minute repaos, timp de $6 \mathrm{~h}$.

După epuizarea programului de agitare, dispersiile au fost filtrate sub vid.

\section{REZULTATE ŞI DISCUTII}

Flotele reziduale de la operaţiile premergătoare tăbăcirii (spălare, înmuiere, cenuşărire) au fost analizate atât înainte, cât şi după tratarea cu complexul mineral de nămol roşu modificat chimic. 
As demonstrated [8], after treatment with mineral complex, the amount of organic matter decreases, which is also reflected by the reduction of chemical oxygen demand by $50 \%$.

The experimental results shown in Figure 1 show that the optimal duration of the transfer process of organic matter into the mineral matrix is 2 hours. In this interval, chemical oxygen demand decreases by more than $85 \%$. In these circumstances, a longer duration is not justified, especially since, prolonging stirring time could cause the reverse process, i.e. desorption of organic matter from particles of adsorbent material.
Aşa cum s-a demonstrat [8], după procesul de tratare cu complexul de minerale, cantitatea de substanţe organice scade semnificativ, aspect reflectat de reducerea consumul chimic de oxigen $\mathrm{cu}$ peste $50 \%$.

Rezultatele experimentale prezentate în Figura 1 evidenţiază faptul că durata optimă a procesului de transfer al substanţelor organice în matricea minerală este de 2 ore. În acest interval de timp, consumul chimic de oxigen scade cu peste $85 \%$. În aceste condiţii, o durată mai mare nu se justifică, cu atât mai mult cu cât prelungirea duratei de agitare ar putea determina procesul invers, respectiv desorbţia materiilor organice de pe particulele de material adsorbant.

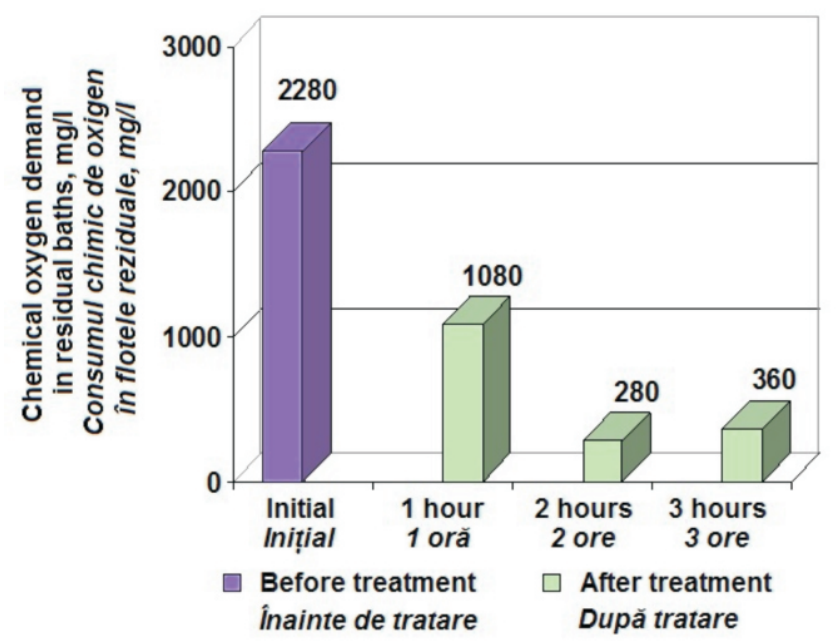

Figure 1. Kinetics of chemical oxygen demand reduction

Figura 1. Cinetica reducerii consumului chimic de oxigen

Increasing the dose of adsorbent material, in solid/liquid ratio ranging from $1 / 10$ to $1.5 / 10$ and $2 / 10$, does not cause a decrease in the amount of organic matter in treated wastewater, moreover, there is a slight growth, as Figure 2 shows, due to the decrease in concentration gradient and shift of balance in the direction of the desorption phenomenon.
Creşterea ofertei de material adsorbant, transpusă în rapoarte solid/lichid de la $1 / 10$ la 1,5/10 şi 2/10, nu determină o scădere a cantităţii de substanţe organice din apele reziduale tratate; mai mult chiar, are loc o uşoară creştere, aşa cum se poate vedea în Figura 2, datorită scăderii gradientului de concentraţie şi deplasării echilibrului în sensul fenomenului de desorbţie. 


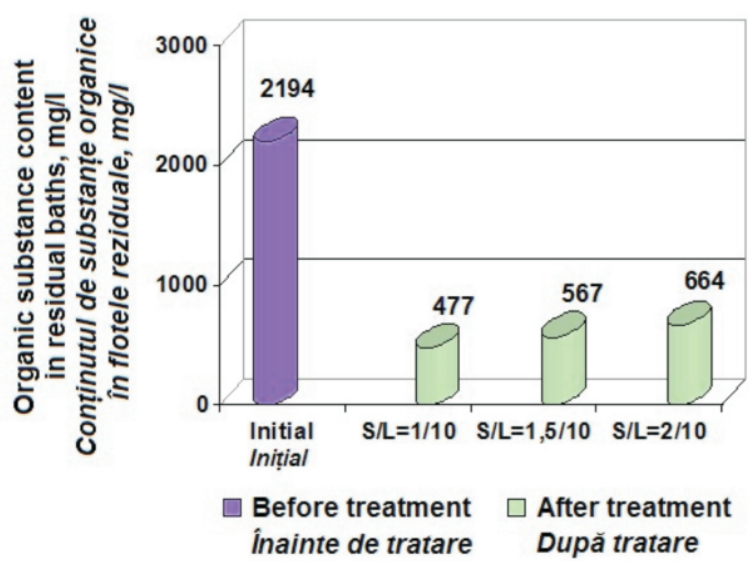

Figure 2. Influence of solid/liquid ratio (S/L) on the reduction of organic substance content

Figura 2. Influenţa raportului solid/lichid (S/L) asupra reducerii conţinutului de substanţe organice

The best solid/liquid ratio is $1 / 10$ and provides an adsorption yield of over $75 \%$ of organic matter contained in the exhausted baths of processes prior to tanning.

Changing the $\mathrm{pH}$ of the onset of organic substance adsorption in the mineral matrix may induce new reactions with balances difficult to achieve in the optimum range and which may give rise to new compounds both in the mineral matrix and with the matters contained in the residual bath, resulting in new variables in the given system, with repercussions on adsorption-desorption balance. This is supported by experiments conducted, the results of which are shown in Figure 3.
Cel mai bun raport solid/lichid se situează la nivelul de 1/10 şi asigură un randament de adsorbţie de peste $75 \%$ din substanţele organice conţinute în flotele epuizate ale proceselor preliminare tăbăcirii pieilor.

Modificarea pH-ului la care debutează adsorbţia substanţelor organice în matricea minerală, poate induce reacţii noi, cu echilibre greu de atins în intervalul optim şi care pot genera compuşi noi atât în matricea minerală, cât şi cu materiile conţinute de flota reziduală, ceea ce conduce la noi variabile în sistemul dat, cu repercusiuni asupra echilibrului adsorbţie-desorbţie. Acest aspect este susţinut de experimentele realizate, ale căror rezultate sunt ilustrate în Figura 3.

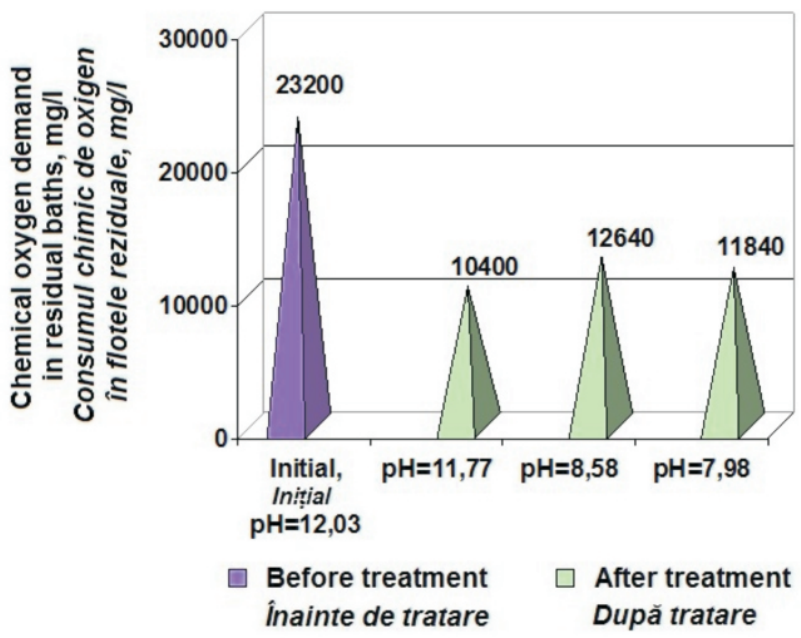

Figure 3. Influence of $\mathrm{pH}$ on chemical oxygen demand reduction

Figura 3. Influenţa pH-ului asupra reducerii consumului chimic de oxigen 
It is clear that reducing the bath $\mathrm{pH}$ before adsorption has a negative effect on the reduction of chemical oxygen demand, and it is preferred that adsorption be performed at the initial $\mathrm{pH}$ of the bath.

Confirmation of the organic matter being retained by the mineral matrix is given by spectral analysis of red mud sediment loaded with substances transferred from wastewater. Figures 4-6 present comparative FT-IR spectra of the mineral complex before adsorption, marked "S123", and after capturing organic matter from residual baths, marked "S1.1", "S1.2", "S1.3", for washing baths, "S2.1", "S2.2", "S2.3" for soaking baths, and "S3.1", "S3.2", "S3.3" for liming baths.
Este evident faptul că reducerea pH-ului flotei înainte de adsorbţie are un efect negativ asupra reducerii consumului chimic de oxigen şi este de preferat ca adsorbţia să se realizeze la pH-ul iniţial al flotei.

Confirmarea faptului că materiile organice sunt reţinute de matricea minerală este dată de analizele spectrale ale sedimentelor de nămol roşu încărcate cu substanţele transferate din apele reziduale. Figurile 4-6 prezintă spectrele FT-IR comparative ale complexului mineral înainte de adsorbţie, notat „S123” şi după captarea materiilor organice din flotele reziduale, notate "S1.1”, „S1.2”, „,S1.3”, pentru flotele de le spălare, „,S2.1”, "S2.2", "S2.3” pentru flotele de la înmuiere şi "S3.1", "S3.2", „S3.3" pentru flotele de la cenuşar.

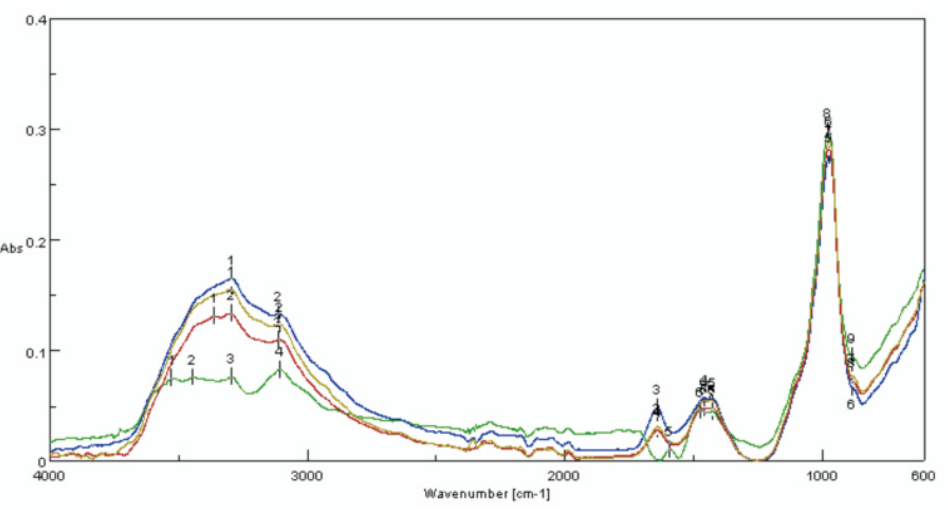

Figure 4. IR spectra of mineral complex before and after adsorption of organic matter from the residual washing bath

Figura 4. Spectrele IR ale complexului mineral înainte şi după adsorbţia materiilor organice din flota reziduală de la spălare

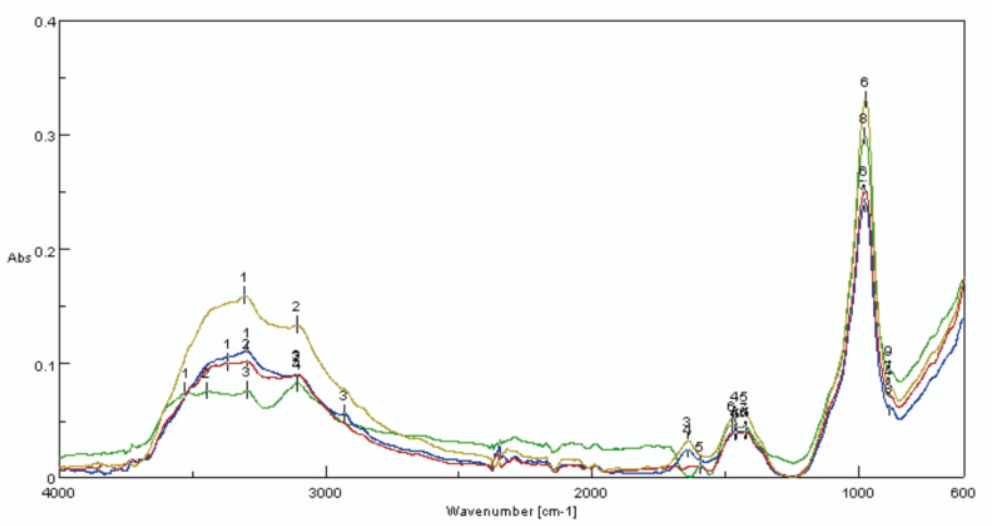

Figure 5. IR spectra of mineral complex before and after adsorption of organic matter from the residual soaking bath

Figura 5. Spectrele IR ale complexului mineral înainte şi după adsorbţia materiilor organice din flota reziduală de la înmuiere 


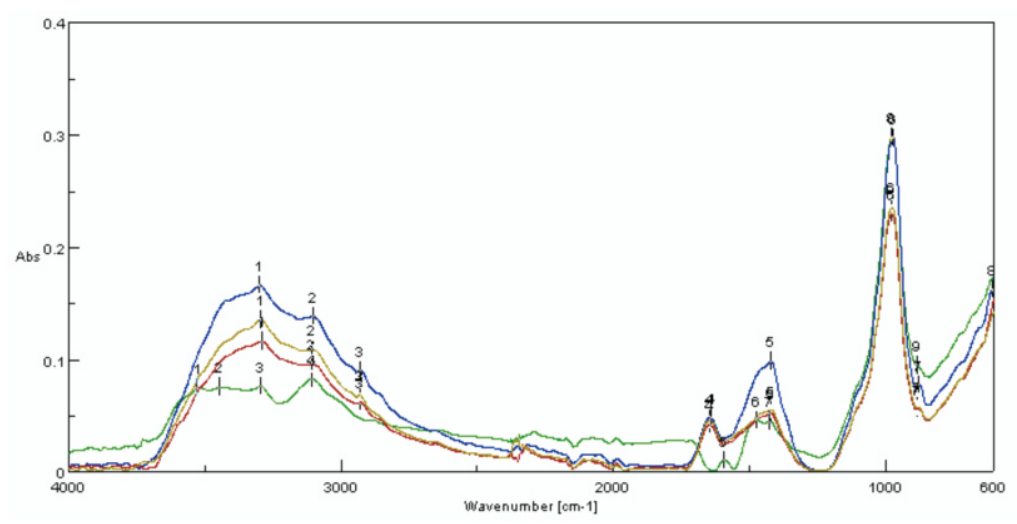

Figure 6. IR spectra of mineral complex before and after adsorption of organic matter from the residual liming bath

Figura 6. Spectrele IR ale complexului mineral înainte şi după adsorbţia materiilor organice din flota reziduală de la cenuşar

Figures 4, 5, 6 show changes in absorbance in the spectral range $3000-3500 \mathrm{~cm}^{-1}$ as a result of changes in concentrations of organic compounds with bonds giving $\mathrm{vNH}$ vibrations in the spectral bands $3310-3350$ $\mathrm{cm}^{-1}, 3050-3200 \mathrm{~cm}^{-1}, 3300-3400 \mathrm{~cm}^{-1}, 3030-3130 \mathrm{~cm}^{-1}$, specific to amines, amides, amino acids and ammonium ion, compounds of residual proteinaceous matter from the leather processing baths.

Figure 7 illustrates the residual baths containing metal-complex dyes, before and after treatment with adsorbent mineral material.
În Figurile 4, 5, 6, se observă modificări ale absorbanţei în intervalul spectral $3000-3500 \mathrm{~cm}^{-1}$, consecinţă a modificărilor de concentraţii ale compuşilor organici cu legături ce dau vibraţii de tip vNH în benzile spectrale $3310-3350 \mathrm{~cm}^{-1}, 3050-3200 \mathrm{~cm}^{-1}, 3300-3400$ $\mathrm{cm}^{-1}, 3030-3130 \mathrm{~cm}^{-1}$, specifice aminelor, amidelor, aminoacizilor şi ionului amoniu, compuşi ai materiilor proteice reziduale din flotele de la prelucrarea pieilor.

în Figura 7 sunt ilustrate flotele reziduale cu conţinut de coloranţi metal-complecşi, înainte şi după tratarea cu materialul mineral adsorbant.

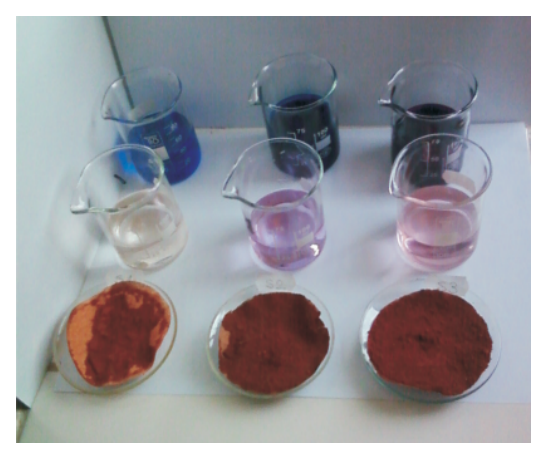

Figure 7. Appearance of residual baths containing dyes, before and after treatment Figura 7. Aspectul flotelor reziduale cu conţinut de coloranţi, înainte şi după tratare

Figures 8-10 comparatively present UV-VIS spectra of residual solutions, marked " $A$ " before treatment, and " $B$ " after treatment, where a significant reduction of dye content, particularly blue dyes, can be seen.
În Figurile 8-10 sunt prezentate spectrele UV-VIS comparative ale soluţiilor reziduale, notate „ $A$ ” înainte de tratare şi „,B” după tratare, în care se poate observa reducerea semnificativă a conţinutului de coloranţi, în special a celor de culoare albastră. 


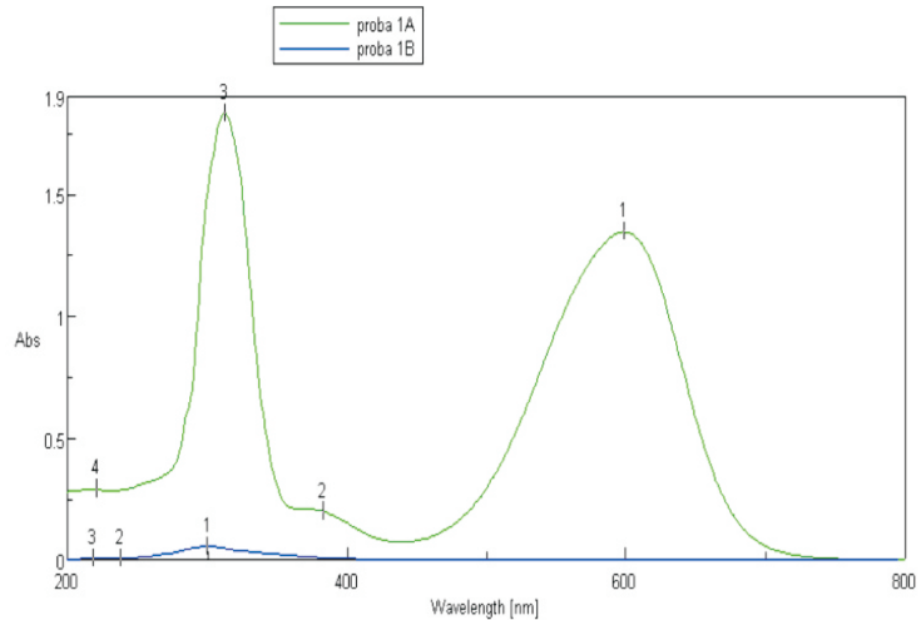

Figure 8. UV-VIS spectra of baths containing blue dye

Figura 8. Spectrele UV-VIS pentru flote cu conţinut de colorant albastru

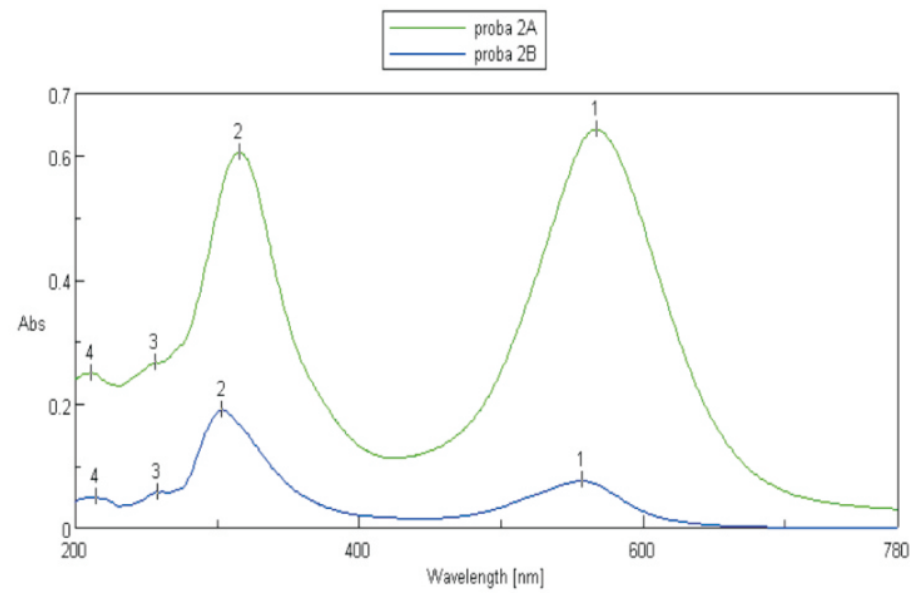

Figure 9. UV-VIS spectra of baths containing violet dye

Figura 9. Spectrele UV-VIS pentru flote cu conţinut de colorant violet

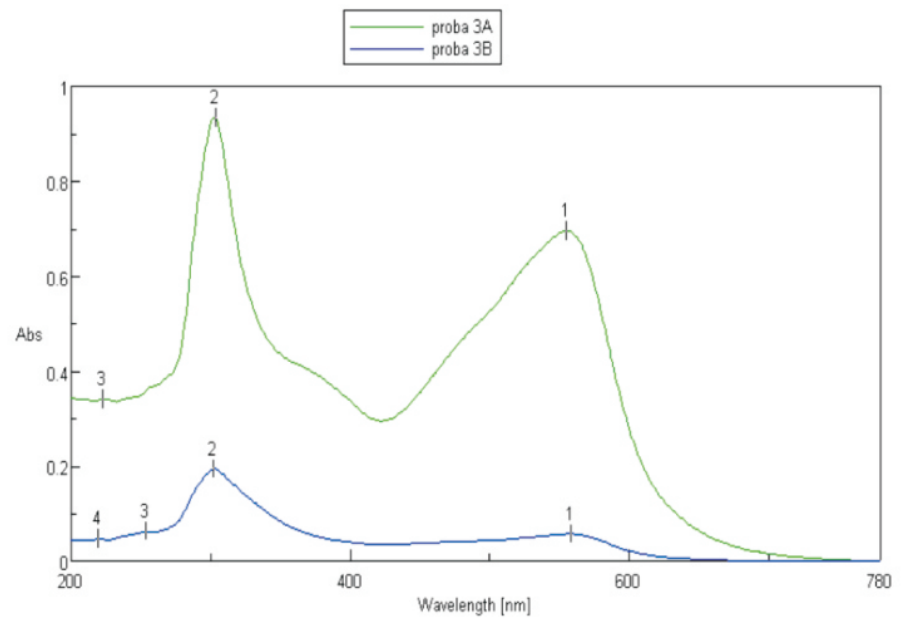

Figure 10. UV-VIS spectra of baths containing bordeaux dye

Figura 10. Spectrele UV-VIS pentru flote cu conţinut de colorant bordo 
Figures 11-13 comparatively present FT-IR spectra of the mineral complex prior to the adsorption of dyes, marked " $\mathrm{s}$ ", and after capturing the dyes, marked "S1IR", "S2-IR", "S3-IR".
În Figurile 11-13 sunt prezentate spectrele FT-IR comparative ale complexului mineral înainte de adsorbţia coloranţilor, notat "s", şi după captarea coloranţilor, notate „S1-IR", „S2-IR", „S3-IR".

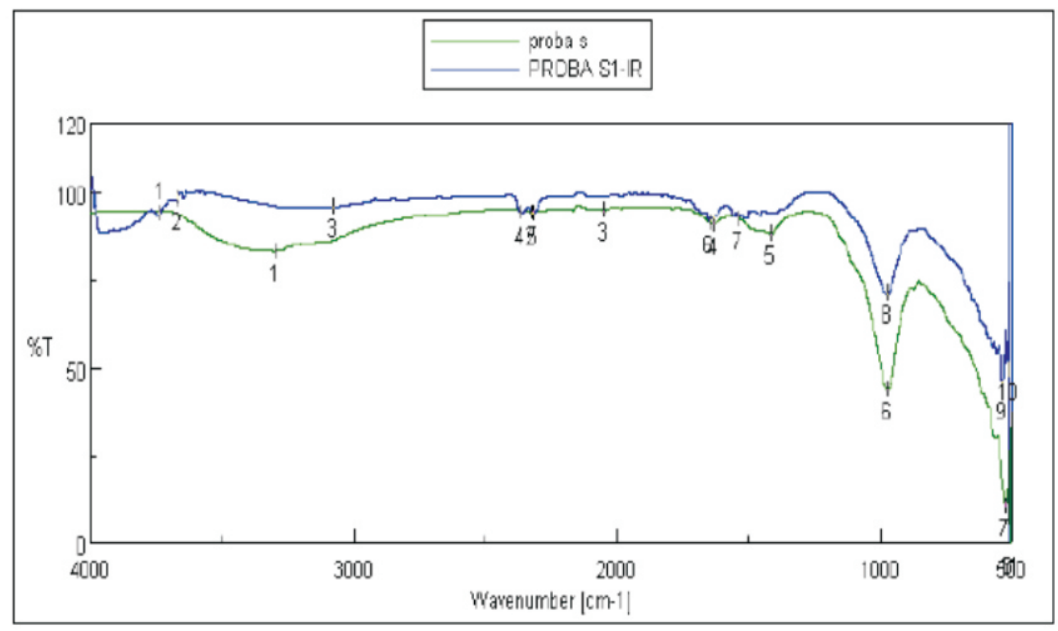

Figure 11. IR spectra of mineral complex before and after adsorption of blue dye

Figura 11. Spectrele IR ale complexului mineral înainte şi după adsorbţia colorantului albastru

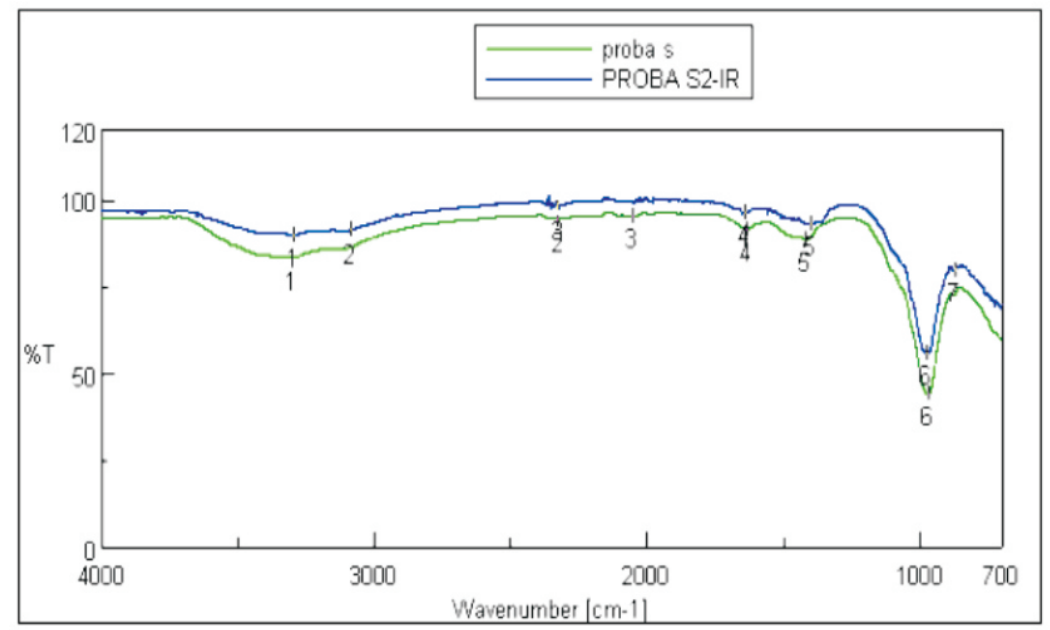

Figure 12. IR spectra of mineral complex before and after adsorption of violet dye Figura 12. Spectrele IR ale complexului mineral înainte şi după adsorbţia colorantului violet 


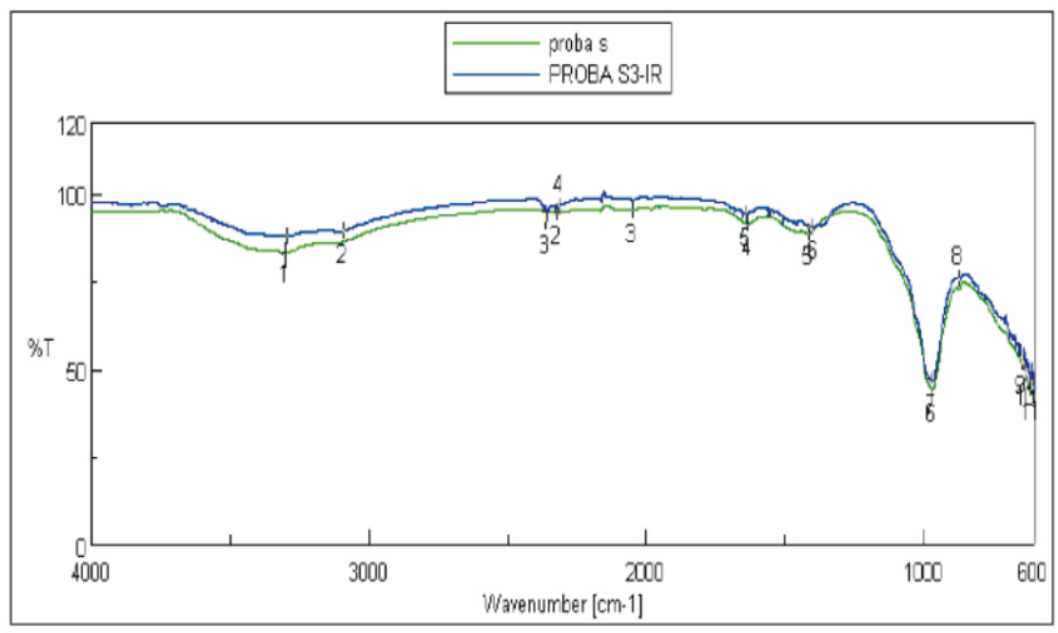

Figure 13. IR spectra of mineral complex before and after adsorption of bordeaux dye

Figura 13. Spectrele IR ale complexului mineral înainte şi după adsorbţia colorantului bordo

IR spectra show that the adsorption is more effective for the unitary blue dye, compared to that of violet and bordeaux dyes, which are a combination of blue dye and red dye, in varying proportions, preponderantly blue for violet and preponderantly red for bordeaux. Figure 7 shows very clearly the coloration in wastewater; for the blue dye, completely removed, the solution became colourless, and for the purple and bordeaux dye, solutions are slightly coloured because of the red dye.

These results are consistent with other research results presented in the literature $[5,6,11]$, which emphasizes the ability of red mud to capture dyes.

\section{CONCLUSIONS}

The mineral complex developed through chemical modification of red mud, waste resulting from the production of alumina, has the ability to retain organic substances from wastewaters.

By treating the residual baths of operations prior to leather tanning using red mud based mineral complex, the chemical oxygen demand of residual baths can be reduced by about $85 \%$.

Mineral complex of chemically modified red mud can capture metal-complex dyes, up to $100 \%$ for dyes in the blue colour range.
Spectrele IR evidenţiază faptul că adsorbţia este mai eficace pentru colorantul albastru, unitar, faţă de cea a coloranţilor violet şi bordo, care sunt combinaţii de colorant albastru şi colorant roşu, în proporţii diferite, preponderent albastru pentru violet şi preponderent roşu pentru bordo. În Figura 7 este foarte evidentă coloraţia în apele reziduale; în cazul colorantului albastru, eliminat în totalitate, soluţia a devenit incoloră, iar în cazul coloranţilor violet şi bordo, soluţiile au tente colorate datorită colorantului roşu.

Aceste rezultate sunt în acord cu rezultatele altor cercetări prezente în literatura de specialitate $[5,6,11]$, care evidenţiază capacitatea nămolului roşu de a capta coloranţi.

\section{CONCLUZII}

Complexul de minerale realizat prin modificarea chimică a nămolului roşu, deşeu de fabricaţie a aluminei, are capacitatea de a reţine substanţe organice din ape reziduale.

Prin tratarea flotelor reziduale rezultate din operaţiile preliminare tăbăcirii pieilor cu complexul de minerale pe bază de nămol roşu se poate reduce consumul chimic de oxigen al flotelor reziduale cu aproximativ $85 \%$.

Complexul mineral al nămolului roşu modificat chimic poate capta coloranţi metal-complecşi, până la $100 \%$ în cazul celor din gama de culoare albastră. 
The transfer of organic matter from baths into the multifunctional mineral matrix is simple, effective, and reproducible, and does not cause particular problems in terms of toxicology and occupational safety.

Removing a large amount of organic residues from the washing, soaking and liming baths has a positive impact on reducing the consumption of chemicals in the pre-treatment plant and the amount of sludge generated, which must subsequently be managed in accordance with increasingly stricter environmental protection regulations.

\section{Acknowledgements}

Experimental research presented in this paper was performed within project no. PN 09.10.02.06 (2013), Nucleu - CERTEXPEL Program, contract no. 10N/2009.
Procesul de transferare a materiilor organice din flote în matricea minerală multifuncţională este simplu, eficace şi reproductibil şi nu induce probleme deosebite sub aspectul toxicologic şi al protecţiei muncii.

Descărcarea celei mai mari cantităţi de reziduuri organice din flotele de spălare, înmuiere şi cenuşărire a pieilor are un impact favorabil asupra reducerii consumului de substanţe chimice în staţia de preepurare şi a cantităţii de nămol generat, care ulterior trebuie gestionat în acord cu reglementările legislative din ce în ce mai severe pentru protecţia mediului.

\section{Mulţumiri}

Cercetările experimentale prezentate în această lucrare s-au realizat în cadrul Programului Nucleu CERTEXPEL, contract 10N/2009, proiect PN 09.10.02.06.

\section{REFERENCES}

1. Niculescu, M., Ionita, A.D., Filipescu, L., Alkaly Earth Metal Salts as Neutralizers of Red Mud from Alumina Refining, Rev. Chim., Bucharest, 2009, 60, 11, 1189-1197.

2. Orescanin, V., Nad, K., Mikelic, L., Mikulic, N., Lulic, S., Utilization of Bauxite Slag for the Purification of Industrial Wastewaters, Process Saf. Environ. Protect., 2006, 84, 4, 265-269.

3. Vaclavikova, M., Misaelides, P., Gallios, G., Jakabsky, S., Hredzak, S., Removal of Cadmium, Zinc, Copper and Lead by Red Mud, and Iron Oxides Containing Hydrometallurgical Waste, Stud. Surf. Sci. Catal., 2005, 155, 517-525.

4. Huang, W., Wang, S., Zhu, Z., Li, L., Yao, X., Rudolph, V., Haghseresht, F., Phosphate removal from wastewater using red mud, J. Hazard. Mater., 2008, 158, 1, 35-42.

5. Tor, A., Cengeloglu, Y., Removal of Congo Red from Aqueous Solution by Adsorbtion Onto Acid Activated Red Mud, J. Hazard. Mater., 2006, 138, 2, 409-415.

6. Wang, S., Boyjoo, Y., Choueib, A., Zhu, Z.H., Removal of Dyes from Aqueous Solution Using Fly Ash and Red Mud, Water Res., 2005, 39, 1, 129-138.

7. Niculescu, M., Ionita, A., Filipescu, L., Bajenaru, S., Niculescu, C., Creating a specific material for isolating residual chromium, Revista de Pielarie Incaltaminte (Leather and Footwear Journal), 2009, 9, 3, 184-195.

8. Niculescu, M., Proving multifunctionality of adsorbent material obtained from red mud (in Romanian), Report 1, 2012, Project no. PN 09.10.02.06, Nucleu - CERTEXPEL Program.

9. Wendling, L.A., Douglas, G.B., Coleman, S., Yuan, Z., Nutrient and dissolved organic carbon removal from water using mining and metallurgical by-products, Water Res., 2012, 46, 8, 2705-2717.

10. Niculescu, M.-D., Simion, D., Sandu, E., Filipescu, L., Characterization of a new material for collection and inertisation of residual chromium, Proceedings of the $3^{\text {rd }}$ International Conference on Advanced Materials and Systems, ICAMS 2010, Bucharest, 16-18 Sept. 2010, 91-96, CERTEX Press, Bucharest, 2010. 
11. Fu, J., Song, R., Mao, W.J., Wang, Q., An, S.-Q., Zeng, Q.-F., Zhu, H.-L., Adsorption of disperse blue 2BLN by microwave activated red mud, Environ. Prog. Sustainable Energy, 2011, 30, 4, 558-566. 